\title{
LESSON STUDY PENGEMBANGAN BAHAN PEMBELAJARAN BERBASIS POTENSI LOKAL UNTUK MENINGKATKAN KOMPETENSI PROFESIONAL GURU SD DI KABUPATEN KEBUMEN
}

\author{
Rokhmaniyah \& Kartika Christy Surandari \\ Universitas Sebelas Maret FKIP PGSD Kampus VI Kebumen \\ rokhmaniyah@staff.uns.ac.id
}

\begin{abstract}
This study aims to: (1) apply lesson study in the development of learning materials based on local potential to improve the professional competence of primary school teachers in Kebumen in 2016; (2) produce learning materials based on local potential through lesson study as an effort to improve the professional competence of elementary school teachers in Kebumen in 2016. This study overall approach development (Research and Development / R \& D). These research subjects were elementary school teachers in Kebumen numbered 50 people. Selection of study subjects according to the school characteristics, was by observing the accreditation status of the school and teacher status. The collection of data were through (1) Focus Group Discussion (FGD). (2) observation, (3) test, (4) study the documentation, (5) interview, (6) checklish behavior, and (7) video. It can be concluded: (1) Lesson study based on learning materials development of local potential improve the professional competence of elementary school teachers in Kebumen 2015. (2) Lesson study can produce learning materials based on local potential quality. Improving the quality of the results of the implementation of lesson study the development of learning materials based on local potential to improve the professional competence of elementary school teachers in Kebumen 2015 reached $90 \%$.
\end{abstract}

Keywords: professional competence, lesson study, the local potential.

\begin{abstract}
ABSTRAK
Penelitian ini bertujuan: (1) menerapkan lesson study dalam pengembangan bahan pembelajaran berbasis poensi lokal untuk meningkatkan kompetensi profesional guru SD di Kabupaten Kebumen tahun 2016; (2) menghasilkan bahan pembelajaran berbasis potensi lokal melalui lesson study sebagai upaya meningkatkan kompetensi profesional guru SD di Kabupaten Kebumen tahun 2016. Penelitian ini secara keseluruhan menggunakan pendekatan pengembangan (Research and Development/R\&D). Subjek penelitian ini ialah para guru SD di Kabupaten Kebumen berjumlah 50 orang. Pemilihan subjek penelitian berdasarkan karakteristik sekolah, yaitu dengan memperhatikan status akreditasi sekolah dan status guru. Pengumpulan data melalui (1) Focus Group Discussion (FGD). (2) observasi, (3) tes, (4) studi dokumentasi, (5) wawancara, (6) behavior checklish, dan (7) video. Hasil penelitian dapat disimpulkan: (1) Lesson study pengembangan bahan pembelajaran berbasis potensi lokapat meningkatkan kompetensi profesional guru SD di Kabupaten Kebumen tahun 2015. (2) Lesson study dapat menghasilkan bahan pembelajaran berbasis potensi lokal yang berkualitas. Peningkatan kualitas hasil penerapan lesson study pengembangan bahan pembelajaran berbasis potensi lokal untuk meningkatkan kompetensi profesional guru SD di Kabupaten Kebumen tahun 2015 mencapai 90\%.

Kata kunci: kompetensi profesional, lesson study, potensi lokal.
\end{abstract}


163 | Premiere Educandum, Volume 6 Nomor 2, Desember 2016, 162 - 173

\section{A. PENDAHULUAN}

Para guru di Indonesia idealnya selalu tampil secara profesional dengan tugas utamanya adalah mendidik, mengajar, membimbing, melatih, mengarahkan, menilai, dan mengevaluasi (Undang-undang Guru dan Dosen Republik Indonesia Nomor 14 Tahun 2005). Di dalam Undang-undang Nomor 20 Tahun 2003 Pasal 39 Ayat 2 dinyatakan bahwa pendidik merupakan tenaga profesional yang bertugas merencanakan dan melaksankan proses pembelajaran, menilai hasil pembelajaran, melakukan pembimbingan dan pelatihan, serta melakukan penelitian dan pengabdian kepada masyarakat, terutama bagi pendidik di perguruan tinggi.

Standar keprofesionalan guru telah dituangkan di dalam Peraturan Pendidikan Nasional Nomor 16 Tahun 2007 tentang Standar Kualifikasi dan Kompetensi Guru. Standar Kualifikasi Guru adalah S1 sesuai dengan latar belakang pendidikan. Adapun, standar kompetensi guru adalah dimensi kompetensi pedagogik, kepribadian, sosial, dan profesional. Seorang guru profesional harus menguasai empat kompetensi tersebut. Sebagai penghargaan terhadap guru yang profesional pemerintah telah memberikan tunjangan profesi guru besaran $100 \%$ dari gaji pokok. Seharusnya, guru yang telah tersertifikasi mampu menunjukkan penguasaan kompetensi guru secara maksimal sebagaimana tertuang dalam Permendiknas Nomor 16 Tahun 2007.

Istilah profesionalisme berasal dari profession. Dalam Kamus Inggris Indonesia, 'profession' berarti pekerjaan (John M. Echols dan Hassan Shadili, 1996:449). Arifin dalam buku Kapita Selekta Pendidikan mengemukakan bahwa profession mengandung arti yang sama dengan kata occupation atau pekerjaan yang memerlukan keahlian yang diperoleh melalui pendidikan atau latihan khusus (Arifin, 1995:105). Seorang profesional akan terus-menerus meningkatkan mutu karyanya secara sadar, melalui pendidikan dan pelatihan (H.A. Tilaar, 2002:86).

Kenyataan di lapangan masih banyak guru yang belum sepenuhnya 
menguasai kompetensi guru secara maksimal khususnya kompetensi yang keempat, yaitu kompetensi profesional. Di dalam Peraturan Pemerintah No 19 tahun 2005, pada pasal 28 ayat 3 disebutkan bahwa kompetensi profesional adalah kemampuan penguasaan materi pembelajaran secara luas dan mendalam yang memungkinkannya membimbing peserta didik memenuhi standar kompetensi yang ditetapkan dalam Standar Nasional Pendidikan. Adapun, di dalam Permendiknas Nomor 16 Tahun 2007 disebutkan bahwa salah satu kompetensi profesional adalah mengembangkan materi pembelajaran yang diampu secara kreatif.

Berdasarkan dari hasil wawancara peneliti terhadap 22 orang guru yang ikut seleksi menjadi guru berprestasi tingkat Kabupaten Kebumen tanggal 1 April 2015 menunjukkan bahwa masih rendahnya kemampuan guru khususnya guru SD untuk menulis karya tulis ilmiah, karya inovatif, dan melakukan penelitian. Hanya beberapa guru yang menunjukkan karya inovasinya berupa modul atau media pembelajaran. Pada umumnya mereka mengalami kesulitan untuk menuangkan gagasan dalam bentuk tulisan. Oleh karena itu, pembelajaran masih didominasi dengan sumber buku paket. Sumber pembelajaran dari buku paket telah membosankan peserta didik. Hal ini karena materi yang ada di buku tersebut tidak kontekstual berkaitan dengan kearifan lokal. Dengan ini, peserta didik menjadi lebih mengenal potensi lokal daerah lain dibandingkan potensi daerahnya sendiri.

Kondisi pembelajaran yang membosankan berpengaruh pada hasil belajar. Oleh karena itu, jika dilihat dari rata-rata hasil ujian sekolah 3 mata pelajaran (Bahasa Indonesia, Matematika, dan IPA) di SD se-Kabupaten Kebumen tahun 2014 hanya sebesar 7,23. Jumlah nilai tertinggi 29,05 dan jumlah nilai terendah 6,55(Data Dikdas Dikpora Kebumen Tahun 2014).

Hasil analisis masalah-masalah di atas antara lain disebabkan karena budaya menulis, berinovasi, dan meneliti belum secara intensif ditanamkan di lingkungan kerja para guru. Kepala sekolah dan pengawas 
165 | Premiere Educandum, Volume 6 Nomor 2, Desember 2016, 162 - 173

dalam memberikan pembinaan dan bimbingan masih dalam aspek administrasi dan kedisiplinan. Bimbingan teknis untuk meningkatkan profesionalisme guru yang dilakukan oleh pemerintah belum menjangkau seluruh guru Indonesia. Selain itu, ruang guru untuk publikasi ilmiah sangat terbatas. Selain penyebab yang berasal dari faktor eksternal (Pemerintah, kepala sekolah, pengawas, organisasi profesi guru) juga dari faktor guru itu sendiri. Kesadaran guru untuk mengikuti bimbingan teknis membuat karya tulis ilmiah maupun karya inovasi yang dilakukan oleh assosiasi dan organisasi profesi sangat rendah.

Cara yang dipandang cukup efektif untuk meningkatkan kompetensi profesional guru secara berkelanjutan adalah melalui lesson study. Sudrajat (2008) menyatakan bahwa lesson study merupakan salah satu upaya untuk meningkatkan proses dan hasil pembelajaran yang dilaksanakan secara kolaboratif dan berkelanjutan oleh sekelompok guru. Lewis (2002) mendiskripsikan proses tersebut sebagai langkah-langkah kolaborasi dengan guru-guru untuk merencanakan (plan), mengamati (observe), dan melakukan refleksi (reflect) terhadap pembelajaran (lesson).Guru yang berkolaborasi dalam penyusunan rencana pembelajaran dapat saling bertukar pikiran untuk mendapatkan solusi guna memecahkan permasalahan yang dihadapi (Rustono, 2007). Secara operasional lesson study dilaksanakan melalui 6 tahapan yaitu (1) membentuk kelompok LS, (2) memfokuskan LS, (3) merencanakan Research Lesson (RL), membelajarkan dan mengamati RL, (5) mendiskusikan dan menganalisis RL dan (6) merefleksikan dan merencanakan kembali LS (Santyasa, 2009).

Potensi lokal adalah segala sesuatu yang merupakan ciri khas kedaerahan dan dapat memberikan manfaat untuk kehidupan bagi penduduk di daerahnya. Dedidwitagama (Akhmad Sudrajat, 2008) menyatakan bahwa keunggulan lokal adalah hasil bumi, kreasi seni, tradisi, budaya, pelayanan, jasa, sumber daya alam, sumber daya 
Rokhmaniyah \& Kartika Christy Surandari:Lesson Study Pengembangan ... |166

manusia atau lainnya yang menjadi keunggulan suatu daerah.

Sesuai dengan hasil penelitian Lilik Mardiningsih (2002:1) dalam penelitian "Upaya Meningkatkan Profesionalisme Guru IPA SMP Di Kecamatan Sleman melalui Optimalisasi Kegiatan Lesson Study" (penelitian tindakan) menunjukkan hasil bahwa kegiatan lesson study dapat meningkatan profesionalisme guru dan berdampak pada peningkatan motivasi belajar siswa. Penelitian ini bertujuan untuk: 1) meningkatkan profesionalisme guru IPA SMP melalui kegiatan lesson study di tingkat kecamatan, 2) mengoptimalkan kegiatan lesson study bagi guru IPA se Kecamatan Sleman, dan 3) meningkatkan kualitas pembelajaran yang berdampak pada peningkatan minat, motivasi, dan hasil belajar bagi siswa.

Rian Anggara dan Umi Chotimah (2012) dalam penelitian "Penerapan Lesson Study Berbasis Musyawarah Guru Mata Pelajaran (MGMP) terhadap Peningkatan Kompetensi Profesional Guru PKn SMP se-Kabupaten Ogan Ilir". Tujuan penelitian untuk mengetahui penerapan lesson study berbasis musyawarah guru mata pelajaran (MGMP) terhadap peningkatan kompetensi profesional guru PKn SMP se-kabupaten Ogan Ilir.

Berdasarkan latar belakang di atas dapat dirumuskan masalah: (1) bagaimana lesson study pengembangan bahan pembelajaran berbasis poensi lokal untuk meningkatkan kompetensi profesional guru SD di Kabupaten Kebumen tahun 2016?; (2) apakah lesson study pengembangan bahan pembelajaran berbasis poensi lokal untuk meningkatkan kompetensi profesional guru SD di Kabupaten Kebumen tahun 2016 dapat menghasilkan bahan pembelajaran yang berkualitas?

Penelitian ini bertujuan, anatara lain: (1) menerapkan lesson study dalam pengembangan bahan pembelajaran berbasis poensi lokal untuk meningkatkan kompetensi profesional guru SD di Kabupaten Kebumen tahun 2016; menghasilkan bahan pembelajaran berbasis potensi lokal melalui lesson study sebagai upaya meningkatkan 
167 | Premiere Educandum, Volume 6 Nomor 2, Desember 2016, 162 - 173

kompetensi profesional guru SD di Kabupaten Kebumen tahun 2016.

\section{B. METODE PENELITIAN}

Penelitian ini secara

keseluruhan menggunakan pendekatan pengembangan (Research and Development/R\&D). Pendekatan penelitian pengembangan ini menggariskan langkah-langkah yang harus diikuti untuk menghasilkan produk tertentu (Sugiono, 2013: 412).

Subjek penelitian ini ialah para guru SD di Kabupaten Kebumen berjumlah 50 orang. Pemilihan subjek penelitian berdasarkan karakteristik sekolah, yaitu dengan memperhatikan status akreditasi sekolah dan status guru.

Pengumpulan data melalui

\section{(1) Focus Group Discussion} (FGD). (2) observasi, (3) tes, (4) studi dokumentasi, (5) wawancara, (6) behavior checklish, dan (7) video. Alat pengumpulan data yang digunakan dalam penelitian ini adalah (1) catatan lapangan (2) pertanyaan wawancara (3) panduan behavior checklish. (4) panduan observasi, (5) lembar soal tes, dan (6) handycam. Dalam hal ini peneliti berkedudukan sebagai instrumen utama (key instrument) yang memiliki kemampuan untuk menyeleksi, menilai, dan memutuskan data. Penentuan validitas data dalam penelitian ini dilakukan dengan triangulasi sumber dan metode.

\section{HASIL DAN PEMBAHASAN}

Berdasarkan hasil penyebaran angket prapenelitian menunjukkan bahwa para guru tidak asing lagi dengan istilah lesson study, tetapi mereka belum memahami lebih dalam dan khususnya para guru SD di Kabupaten Kebumen belum pernah melaksanakan lesson study. Oleh karena itu, para guru sangat merespon terhadap kegiatan lesson study sebanyak 91\%. Para guru yang menyatakan bahwa lesson study dapat meningkatkan kompetensi, kreativitas, dan pengembangan kariernya sebanyak di atas 50\%. Potensi lokal dapat dikembangkan melalui pembelajaran di sekolah. Hal ini juga didukung oleh pernyataan guru sebanyak 96,8\%. Selain itu juga, $92,6 \%$ guru menyatakan bahwa potensi lokal dapat sebagai media pembelajaran. Tidak semua guru 
Rokhmaniyah \& Kartika Christy Surandari:Lesson Study Pengembangan ... |168

membuat bahan pembelajaran yang baru di setiap semester rata-rata pembelajaran sama dari tahun sebelumnya dan hanya menggunakan buku paket. Peserta didik mengalami kobosanan.

Penerapan Lesson Study Berbasis Potensi Lokal untuk Meningkatkan Kompetensi Profesional Guru SD di Kabupaten Kebumen.

\section{Pelaksanaan Lesson Study I}

\section{Tahap Plan}

Kegiatan lesson study dalam penelitian ini diawali dengan workshop tanggal 6 Juli 2015. Sebelum workshop, peserta mengisi angket prapenelitian. Peserta workshop nampak tertarik memperhatikan penjelasan materi oleh narasumber khususnya ketika membahas penulisan bahan pembelajaran berbasis potensi lokal.

Pada tahap perencanaan ini, peserta dikelompokkan yang masingmasing kelompok berjumlah 4 atau 5 orang. Setelah peserta berkelompok, mereka melakukan FGD 1 dengan tugas melakukan analisis silabus dan potensi lokal yang kemudian dituliskannya dalam kertas folio bergaris. Selanjutnya, peserta dalam kelompok mulai menulis draf bahan pembelajaran berbasis potensi lokal sesuai dengan tugas. Peserta tampak semangat menulis dan bertanya. Bahan pembelajaran yang harus dibuat harus memenuhi unsur-unsur : Identitas bahan pembelajaran, Kegiatan Pembelajaran yang akan dilaksanakan, Kemampuan yang Dikembangkan, Pemetaan Indikator, Materi, Lembar Kerja Siswa, Rangkuman, Tes Formatif/Lembar Evaluasi, Kunci Jawaban, dan panduan pelaksaan.

Pada FGD I, peneliti mengamati penulisan draf bahan pembelajaran berbasis potensi lokal yang dikembangkan di lima wilayah kecamatan sebagai berikut. Penulisan draf bahan pembelajaran tahap satu dilanjutkan di luar jam lesson study. Selanjutnya, kelompok melakukan perbaikan draf bahan pembelajaran yang berbasis potensi lokal. Kemudian, peneliti memandu untuk menentukan jadwal open class ke-1 dan menganalisis kebutuhan sarana yang dibutuhkan seluruh kelompok lesson study untuk open class. Para kelompok menetapkan guru model yang akan tampil mengelola 
169 | Premiere Educandum, Volume 6 Nomor 2, Desember 2016, 162 - 173

pembelajaran untuk menguji

keterbacaan draf bahan pembelajaran berbasis potensi lokal yang telah ditulis.

\section{Tahapan Do}

Open class dilaksanakan selama 5 hari. Guru model siap mengelola pembelajaran. Open class dihadiri oleh pejabat, dosen, serta teman satu kelompok lesson study sebagai pengamat. Para pengamat mengamati pengelolaan kelas untuk uji keterbacaan bahan pembelajaran berbasis potensi lokal dari belakang kelas.

Berdasarkan hasil pengamatan menunjukkan bahwa peserta didik tampak senang dan gembira dengan mengamati potensi lokal daerah Kabupaten Kebumen melalui gambar dan video. Dari bahan pembelajaran berbasis potensi lokal yang disajikan ke peserta didik tampak peserta didik juga tidak mengalami kesulitan dalam membaca dan mengerjakan Lembar Kerja Siswa (LKS).

\section{Tahapan see}

\section{Pelaksanaan Lesson study}

tahap I masih belum maksimal karena bahan pembelajaran belum menggali potensi di masing-masing wilayah secara menyeluruh.

\section{Pelaksanaan Lesson Study II}

\section{Tahapan Plan}

Lesson Study II diawalai dengan kegiatan FGD ke-2 pada tanggal 10 Agustus 2015. Tim peneliti menyampaikan hasil refleksi lesson study I. Adanya kendala pada pelaksanaan Lesson Study I, peneliti membuat rencana dan melaksanakan perbaikan tindakan Lesson Study II. Guru model dan kelompok menyiapkan RPP, LCD, gambar potensi lokal, dan lembar kerja yang akan dibagikan ke peserta didik.

\section{Tahapan Do}

Tahapan Do diisi dengan kegiatan open class ke-2. Open class ke-2 bermaksud melakukan uji keterbacaan bahan pembelajaran berbais potensi lokal yang telah dilakukan perbaikan pada tahapan plan lesson study II. Pembelajaran berfokus pada siswa dan guru lebih dominan sebagai fasulitator. Peneliti, dosen, guru kelas, kepala sekolah dan pejabat Bappeda sebagai tim pengamat. Berikut ini adalah hasil monitoring pertama dan kedua draft bahan pembelajaran. 


\section{Tahapan see}

Pada lesson study II ditemukan beberapa kelebihankelebihan penerapan lesson study di antaranya: (1) siswa lebih berkembang keterampilan inkuiri (inquiry skill), (2) Aktivitas pembelajaran siswa meningkat sehingga siswa lebih senang dalam belajar, (3) siswa lebih berkesempatan untuk mencari informasi yang lebih luas, (4) melalui presentasi hasil riset, siswa lebih mengembangkan kemampuan komunikasi dan menambah rasa percaya diri, (5) memberikan kesempatan kepada siswa untuk mengaplikasikan pengetahuan yang mereka miliki dalam dunia nyata,

Lesson study untuk Menghasilkan Bahan Pembelajaran Berbasis Potensi Lokal yang Berkualitas

Berdasarkan observasi dapat disimpulkan bahwa semua peserta telah berusaha menggali dalam memanfaatkan potensi lokal yang ada di sekitar sekolah masing-masing walaupun kadar pemanfaatanya masih sangat terbatas dan berbedabeda antara satu sekolah dengan sekolah lainnya.
Hasil monitoring penyusunan draf bahan pembelajaran berbasis potensi lokal pada unsur: identitas bahan pembelajaran, kegiatan pembelajaran, kemampuan yang dikembangkan, dan pemetaan indikator pada umumnya telah dilakukan dengan tepat sesuai dengan ketentuan. Namun, ada sebagian peserta belum menuliskannya.

Hasil monitoring dan evaluasi di setiap peserta telah menghasilkan draf bahan pembelajaran. Berdasarkan wawancara dengan peserta bahwa lesson study menambah wawasan ilmu dalam menyusun bahan pembelajaran, guru terbantu dengan alternatif bahan pembelajaran berbasis potensi lokal, termotivasi untuk lebih baik dalam mengajar. Secara kualitas bisa diukur dengan jumlah guru/peserta lessen study 50 orang, yang mampu menyusun bahan pembelajaran sesuai dengan kriteria penulisan bahan pembelajaran berbasis potensi lokal sebanyak 46 orang. Dengan demikian, dapat dikatakan bahwa 90\% guru telah mampu menghasilkan modul berbasis potensi lokal yang berkualitas sesuai kriteria. Selain itu, juga terjadi 
171 | Premiere Educandum, Volume 6 Nomor 2, Desember 2016, 162 - 173

peningkatan hasil belajar siswa mengalami peningkatan dari 72,3 selama pembelajaran dari open class I menjadi 76. Lebih jelasnya perhatikan ke open class III. Rerata hasil belajar Tabel 1 berikut ini.

siswa dari peserta lesson study

Tabel 1. Hasil Monitoring Progres Penulisan Draf Bahan Pembelajaran Berbasis Potensi Lokal

\begin{tabular}{|c|c|c|c|c|}
\hline & \multicolumn{2}{|c|}{ Monitoring I } & \multicolumn{2}{c|}{ Monitoring II } \\
\hline $\begin{array}{c}\text { No. } \\
\text { Butir }\end{array}$ & $\begin{array}{c}\text { Jumlah } \\
\text { Ya }\end{array}$ & $\begin{array}{c}\text { Jumlah } \\
\text { Tidak }\end{array}$ & $\begin{array}{c}\text { Jumlah } \\
\text { Ya }\end{array}$ & $\begin{array}{c}\text { Jumlah } \\
\text { Tidak }\end{array}$ \\
\hline 1 & 48 & 2 & 50 & 0 \\
2 & 49 & 1 & 50 & 0 \\
3 & 27 & 3 & 50 & 0 \\
4 & 46 & 4 & 50 & 0 \\
5 & 49 & 1 & 48 & 2 \\
6 & 21 & 29 & 40 & 10 \\
7 & 42 & 8 & 43 & 7 \\
8 & 45 & 5 & 45 & 5 \\
9 & 45 & 5 & 40 & 10 \\
10 & 45 & 5 & 47 & 3 \\
11 & 26 & 24 & 40 & 10 \\
12 & 24 & 26 & 48 & 2 \\
13 & 23 & 27 & 40 & 10 \\
14 & 21 & 29 & 43 & 7 \\
15 & 36 & 14 & 48 & 2 \\
16 & 35 & 15 & 42 & 8 \\
17 & 36 & 14 & 47 & 3 \\
18 & 35 & 15 & 45 & 15 \\
19 & 25 & 25 & 48 & 2 \\
20 & 24 & 26 & 38 & 12 \\
\hline
\end{tabular}

\section{SIMPULAN DAN SARAN}

\section{Simpulan}

Dari hasil penelitian dapat disimpulkan: (1) Lesson study pengembangan bahan pembelajaran berbasis potensi lokapat meningkatkan kompetensi profesional guru SD di Kabupaten Kebumen tahun 2015. Pelaksanaan melalui perencanaan/plan pembelajaran dan penyusunan perangkat pembelajaran dengan focus group discusion/ FGD I dan II. Pelaksanaan/Do diimplementasikan dengan open class I dan II serta refleksi/see untuk mengevaluasi pembelajaran supaya lebih baik dilakukan dengan FGD. (2) Lesson 
Rokhmaniyah \& Kartika Christy Surandari:Lesson Study Pengembangan ... |172

study dapat menghasilkan bahan pembelajaran berbasis potensi lokal yang berkualitas. Peningkatan kualitas hasil penerapan lesson study pengembangan bahan pembelajaran berbasis potensi lokal untuk meningkatkan kompetensi profesional guru SD di Kabupaten Kebumen mencapai $90 \%$. Pembelajaran berbasis potensi lokal siswa menjadi lebih tertarik, senang, antusias, dan hasil belajarnya meningkat.

\section{Saran}

1. Guru SD

Guru senantiasa meningkatkan profesionalismenya dengan kreatif menulis bahan pembelajaran baik berbasis nasional maupun lokal.

2. Sekolah

Sekolah memberikan dukungan kepada guru-guru untuk mengikuti lesson study dengan harapan untuk meningkatkan kenerjanya.

3. Peneliti Selanjutnya

Para peneliti selanjutnya bekerja sama dengan BAPPEDA untuk mengembangkan lesson study di wilayah lain.

\section{DAFTAR RUJUKAN}

Anggara, Rian dan Chotimah, Umi. 2013. Penerapan Lesson Study Berbasis Musyawarah Guru Mata Pelajaran (Mgmp) Terhadap Peningkatan Kompetensi Profesional Guru Pkn Smp Se-Kabupaten Ogan Ilir http://eprints.unsri.ac.id/1421 /1.Diunduh tanggal 20 April 2015.

Depdiknas.2003. Undang-undang Republik Indonesia Nomor 20 Tahun 2003 tentang Sistem Pendidikan Nasional

- 2005. Undang-undang Republik Indonesia Nomor 14 Tahun 2005 tentang Guru dan Dosen

2013. Peraturan Pemerintah Nomor 32 Tahun 2014 tentang Perubahan atas Peraturan Pemerintah Nomor 19 Tahun 2005 tentang Standar Nasional Pendidikan . 2007. Peraturan Menteri Pendidikan Nasional Nomor 16 Tahun 2007 tentang Standar Kualifikasi dan Kompetensi Guru

Echols John M. dan Hassan Shadili. 1996. Kamus InggrisIndonesia. Jakarta: PT Gramedia. Cetakan ke-23.

Lewis, C. 2002. Lesson study: A handbook of teacher-led instructional change. Philadelphia: Research for Better Schools.

Mardaningsih, Lilik. 2013.Upaya Meningkatkan Profesionalisme Guru IPA 
173 | Premiere Educandum, Volume 6 Nomor 2, Desember 2016, 162 - 173

SMP Di Kecamatan Sleman melalui Optimalisasi Kegiatan Lesson Study. Tesis. Program Pascarjana, Universitas Negeri Yogyakarta, http://eprints.uny.ac.id/12556 /1/abstrak-lilik-mardiningsih. Diunduh tanggal 20 April 2015.

Santyasa WI. 2009. Implementasi Lesson study Dalam Pembelajaran. Makalah dalam "Seminar Implementasi Lesson Study dalam Pembelajaran bagi Guru-Guru TK, Sekolah Dasar dan Sekolah Menengah Pertama di Kecamatan Nusa Penida, 24 Januari 2009, Nusa Penida.

Smith, S.G. (2002). Educational action research. Diambil pada tanggal 18 Agustus 2005, dari http://www.triangle.co.uk/ear.

Rustono,E.H.M. Abdul Muin. 2007. Lesson study Sebagai Model Bimbingan Mahasiswa PGSD Pada Program Pengalaman Lapangan Di Sekolah Dasar. Penelitian Pembinaan. Fakultas Ilmu Pendidikan UPI.

Sudrajat, A. 2008. Lesson Study Untuk Meningkatkan Proses Dan Hasil Pembelajaran.Semarang.http: //akhmadsudrajat.wordpress.c om/2008/02/22 diakses September 2012. . 2008. Pendidikan Berbasis Keunggulan Lokal. https://akhmadsudrajat.wordp ress.com/2008/08/13/konsepdasar-pendidikan-berbasis- keunggulan-lokal-pbkl.

Diunduh pada tanggal 15 April 2015.

Tim Widyaiswara LPMP Jawa Tengah. 2008. Langkahlangkah Penyusunan Lesson Study. Semarang: LPMP Jawa Tengah.

Usman, Moh. User. 1992. Menjadi Guru Profesional. Bandung: PT Remaja Rosdakarya.

Usman, Husaini. 2006. Metodologi Penelitian Sosial. Jakarta: Bumi Aksara

Widowati.A. 2012. Optimalisasi Potensi Lokal Sekolah Dalam Pembelajaran Biologi Berbasis Konstruktivisme. Majalah Ilmiah Pendidikan. Jurusan Kurikulum dan Teknologi Pendidikan FIP UNY.

Yusak, Muchlak. 2008. Lesson Study. Jakarta.

Yamin, $\quad$ Martinis. 2008. Profesionalisme Guru dan Implementasi KTSP. Jakarta: Gaung Persada Press. 